\begin{tabular}{|c|}
\hline 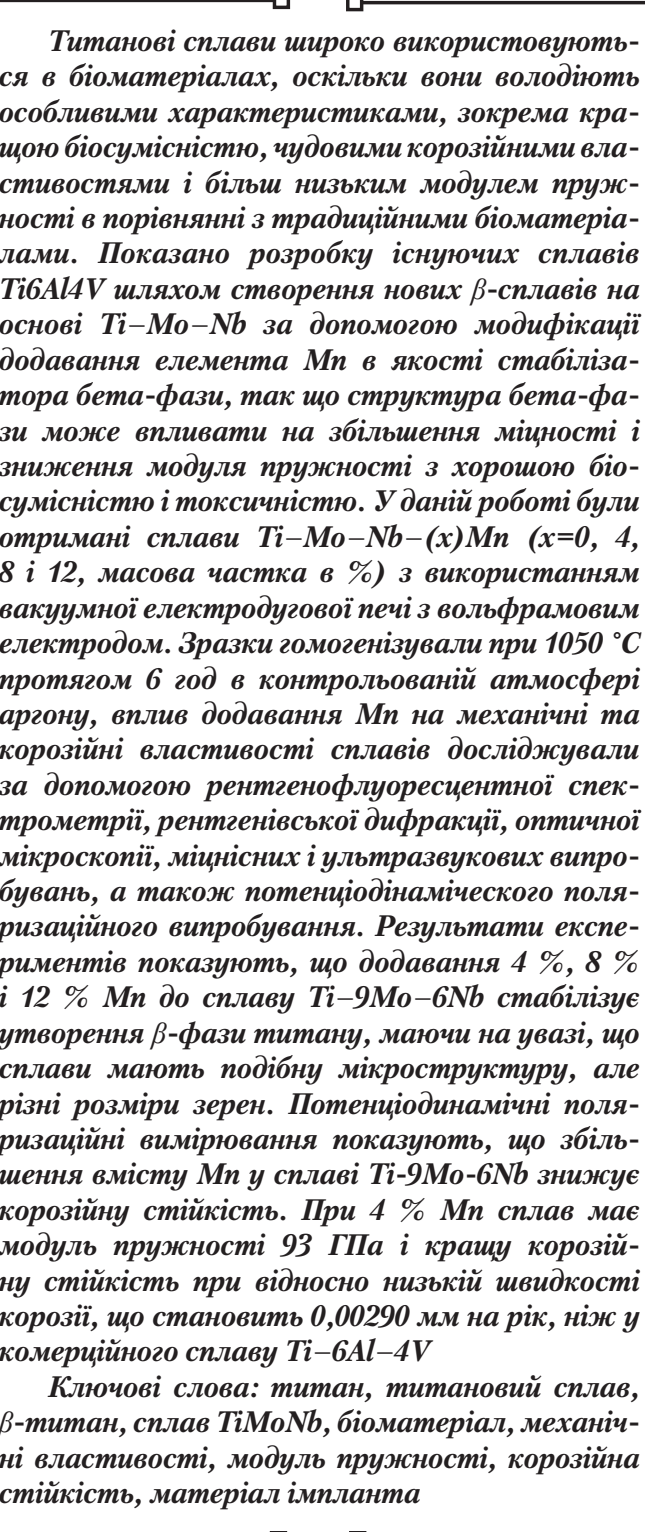 \\
\hline
\end{tabular}

Титанові сплави иироко використовуються в біоматеріалах, оскільки вони володіють стивостями $і$ більш низъким модулем пружності в порівнянні з традичійними біоматеріа основі $\mathrm{Ti}-\mathrm{Mo}-\mathrm{Nb}$ за допомогою модифікаці додавання елемента Мn в якості стабілізазниження модуля пружності з хорочою біовакуумної електродугової печі з вольфрамовим аргону, вплив додавання Мп на механічні та корозійні властивості сплавів досліджували мікроскопї̈, міинісих і ультразвукових випробувань, а також потенціодінаміческого поляризачіиного випробування. Результати експе (1)-9Mo-6Nb cmárizizye утворення $\beta$-фази титану, маючи на увазі, шо сплави мають подібну мікроструктуру, але шення вмісту Мп у сплаві Ti-9Mo-6Nb знижуе корозіину стіикість. При 4 \% Мп сплав мае корозї, що становить 0,00290 мм на рік, ніж $у$ омериійного сплаву $\mathrm{Ti}-6 \mathrm{Al}-4 \mathrm{~V}$ $\beta$-титан, сплав TiMoNb, біоматеріал, механіч стійкість, матеріал імпланта
UDC 621

DOI: $10.15587 / 1729-4061.2020 .193932$

\section{MICROSTRUCTURE, MECHANICAL PROPERTIES, AND CORROSION BEHAVIOR OF NEW $\beta$-TYPE Ti-Mo-Nb BASED ALLOYS BY MN ADDITION FOR IMPLANT MATERIAL}

\author{
Cahya Sutowo \\ Master of Engineering* \\ E-mail: csutowo@yahoo.com \\ Sugeng Supriadi \\ $\mathrm{PhD}$, Associate Professor \\ Department of Mechanical Engineering** \\ E-mail: sugeng@eng.ui.ac.id \\ Andika Widya Pramono \\ Doctor of Engineering, Associate Professor \\ Research Center of Metallurgy and Material \\ Indonesian Institute of Sciences \\ Building 470, Kawasan Puspiptek Serpong, \\ Tangerang Selatan 15314, Indonesia \\ E-mail: andika_pram@yahoo.com \\ Bambang $\mathbf{S}$ uharno \\ Doctor of Engineering, Professor* \\ E-mail: suharno@metal.ui.ac.id \\ *Department of Metallurgy and Material Engineering** \\ **University of Indonesia \\ Jl. Margonda Raya, Pondok Cina, Beji, \\ Depok, West Java, Indonesia, 16424
}

\section{Introduction}

There are several advantages of using titanium (Ti) over metals as a biomedical implant material: for example, its mass density, specific strength, elastic modulus, corrosion resistance, and better biocompatibility [1]. Moreover, Tibased alloys have attracted wide attention because of their high strength-to-density ratio, high corrosion resistance, and good biocompatibility on implantation in the body [2, 3].

Titanium and its alloys are used in the biomedical field in the manufacture of various orthopedic implants for knee or shoulder joints, orthodentistry, and cardiovascular coronary stents [4-6]. However, there are special requirements that must be met for these purposes: namely, the biomechanical orthopedic and orthodentic implants must be compatible with tissues in the human body to prevent them from being rejected when implanted [7].
The most widely used titanium-containing materials are commercially pure titanium (CP-Ti) and the titanium alloy known as $\mathrm{Ti}-6 \mathrm{Al}-4 \mathrm{~V}$. However, despite being in wide use, both still have shortcomings when used as biomaterials because of their relatively high elastic modulus. CP-Ti has a hexagonal close packed (HCP) crystal structure with an $\alpha$-phase, implying that it has a high elastic modulus of $120 \mathrm{GPa}$, and the Ti-6Al-4V alloy also has an HCP crystal structure, but with an $\alpha-\beta$-phase, implying that the elastic modulus is $110 \mathrm{GPa}$, compared with cortical human bone that has an elastic modulus of $10-30 \mathrm{GPa}$ [8].

A significant difference between the elastic modulus of the bone and implant may result in pain being felt in the bone, which is often referred to as the stress shielding effect. This effect is a direct result of the orthopedic implant supporting most of the load and causing excessive movement, which prevents the burden from being channeled from the 
implant to the bone. This results in a relaxing of the contact area between the implant and the bone, thus inhibiting the growth of new bone tissue, isolating the implant from its surroundings, and preventing the desired osteointegration of the implant [9]. The microstructure and mechanical properties of $\mathrm{Ti}-6 \mathrm{Al}-4 \mathrm{~V}$ alloys can be modified by changing the combination of elements and applying thermomechanical treatment [10-12]. It has been reported that Al- and V-containing alloys release metal ions that cause health problems in humans $[13,14]$. With this in mind, titanium alloys have been developed using molybdenum or niobium to replace vanadium [15-17].

\section{Literature review and problem statement}

Biomaterials are materials that can be used as medical devices and are able to interact with biological systems [18]. So the biomaterial requirements must have biocompatibility properties, namely the ability of a material to work in harmony with the body without causing other harmful effects. So the basic properties that must be possessed by biomaterials are biomechanical and biomedical properties (toxicity and osteointegration). Biomechanical properties must be compatible with body tissues without any rejection reaction of body tissues when applied to the human body [7].

There are five types of materials commonly used as biomedical implants, namely metals, polymers, ceramics, composites, and natural materials. Among the five biomaterials mentioned above, the use of metal biomaterials has the longest history since the use of stainless steel as a biomaterial [19].

Compared to other biomaterials such as ceramics and polymers, metals have better mechanical properties, including strength, toughness, hardness, buildability, corrosion resistance, and biocompatibility as a replacement for damaged bones. However, biomaterials not only function as a substitute for hard tissue (bone) but also function as a medium for soft tissue (muscle) growth. Metal biomaterials are widely used for replacing implanted bones, such as in the hips, knee joints and bones and starting to be used for artificial heart valves or pacemakers. There are three types of metal materials that have good biocompatible properties, namely stainless steel free nickel, $\mathrm{Co}-\mathrm{Cr}$ cobalt alloys and titanium alloys. The use of metal alloys as biomaterials to improve the properties of pure metals that are often used.

Several studies show that the modulus of elasticity of titanium alloy is much higher than that of human bones. Elastic modulus of human bones for cortical bone ranges from 13-28 GPa. However, when compared with the elastic modulus of implant material currently used such as stainless steel (190-210 GPa), Co-Cr alloy (210-253 GPa), the elastic modulus of titanium alloys is still lower at around $110 \mathrm{GPa}$. Significant differences in the elastic modulus of bone and orthopedic implant material can cause bone pain or stress shielding effect because the implant material supports the majority of the load. In addition, the large elastic modulus of bone and large implant material cause relatively excessive movement between the bone and the implant. This excessive movement prevents the burden that must be transferred from the implant to the bone. The contact area between the orthopedic implant and the bone will relax so that it will inhibit the growth of new bone tissue [9].
Titanium is the latest metallic biomaterial after stainless steel and cobalt-based alloys and most popular. Pure titanium and its alloys have become attractive biomaterials due to their excellent biocompatibility, light weight, corrosion resistance, specific strength, and lower modulus compared to stainless steels and $\mathrm{Co}-\mathrm{Cr}$ alloys. Apart from its superior mechanical properties, another reason for choosing titanium and its alloy is because stainless steel and cobalt alloys contain hazardous elements such as $\mathrm{Ni}, \mathrm{Cr}, \mathrm{Co}$. However, the mechanical properties of pure titanium are considered insufficient to meet the needs of biomaterials requiring high strength as a substitute for hard tissue [7].

Pure titanium has two types of crystalline forms. At room temperature, pure titanium has the hexagonal closed packed (HCP) structure which is commonly called the alpha phase $(\alpha)$. At a temperature of $883^{\circ} \mathrm{C}\left(1621^{\circ} \mathrm{F}\right)$ and atmospheric pressure, titanium crystals will transform into body-centered cubic (BCC) or known as the beta $(\beta)$ phase and form solid solutions through the addition of a number of combining elements. Manipulation of these crystal variations through the addition of combining elements and thermomechanical processes is the basis of the development of alloys and the characteristic of titanium [20].

To overcome the limitations of pure titanium, an $\alpha+\beta$ type titanium alloy was developed. In the titanium alloy type $\alpha+\beta$ has a combined composition of $\alpha$ and $\beta$ phases at room temperature. The most commonly known type $\alpha+\beta$ titanium alloy is Ti-6Al-4V (Extra Low Interstitial-ELI), where $\mathrm{Al}$ acts as an $\alpha$ phase stabilizer and $\mathrm{V}$ as a $\beta$ phase stabilizer. The next research that has been carried out is the development of Ti6Al6Mo and Ti6Al6Nb titanium alloys where the elements $\mathrm{Nb}$ and Mo are used to replace the element V. However, the resulting final elastic modulus is still relatively high at around $115 \mathrm{GPa}[15,17,21]$.

Titanium alloy biomaterials that contain only a $\beta$-phase have also been produced by substituting Al for $\mathrm{Mo}$ and $\mathrm{Nb}$ as a phase stabilizer to increase the material strength and decrease the elastic modulus. Using $\mathrm{Nb}$, $\mathrm{Mo}, \mathrm{Cr}, \mathrm{Zr}$, Ta, Sn, Fe, Mn, and other elements to act as $\beta$-phase stabilizers, $\beta$-type titanium alloys that are free from any toxic elements and have low elastic modulus have been developed [22, 23].

Owing to the high price of rare metal elements such as $\mathrm{Nb}, \mathrm{Ta}, \mathrm{Mo}$, and Zr, elements such as $\mathrm{Mn}, \mathrm{Sn}, \mathrm{Fe}$, and $\mathrm{Cr}$ have been proposed as $\beta$-phase stabilizers because of their availability and low cost. Several research studies have been carried out on the tailoring of the biocompatibility, cytotoxicity, and mechanical properties of a $\mathrm{V}$-free and low-cost $\mathrm{Ti}-4.7 \mathrm{Mo}-4.5 \mathrm{Fe}$ alloy to suit the requirements of its application in the biomedical field [24]. Further development of a Ti-Mo-Nb-based alloy is a $\beta$-type titanium alloy, where $\mathrm{Mo}$ and $\mathrm{Nb}$ are replaced with easy-to-obtain and low-cost metals [25-29].

$\mathrm{Ti}-\mathrm{Mn}$ binary alloys with different combinations of metal have also been designed to achieve a higher strength material, where Mn was chosen for the purpose of reducing costs, because the cost of this metal is very low compared with that of other desirable alloying elements such as Nb and Mo. The titanium alloys were prepared and heat treated; then, the influence of $\mathrm{Mn}$ on the phase content and microhardness was evaluated [30].

Research attempts that have been carried out ultimately are aimed to improve the function and life span of implants 
in the human body by significantly reducing the differences in elastic modulus between human bone tissue and implant material. The novelty carried out in this study is the design of a new $\beta$-type $\mathrm{Ti}-9 \mathrm{Mo}-6 \mathrm{Nb}$ titanium alloy composition that has never been done and the addition of the Mn element that has not been widely used to produce beta phase and optimum mechanical properties. Further development of biomaterials using $\beta$-type titanium alloys that are free of toxic elements and their relatively low elastic modulus has been the focus of current research.

In this study, a new $\mathrm{Ti}-\mathrm{Mo}-\mathrm{Nb}-(x) \mathrm{Mn}$ alloy, synthesized using an electric vacuum arc furnace with a tungsten electrode, is presented. The effects of adding low-cost Mn in different percentages to reduce the amounts of or substitute for niobium and molybdenum on the alloy microstructures, mechanical properties, and corrosion behavior are reported.

\section{The aim and objectives of the study}

The aim of the study is to improve the mechanical properties and corrosion behaviour as the development of implant material by adding manganese to reduce the niobium and molybdenum using.

To achieve this aim, the following objectives are accomplished:

- to determine the effect of the element Mn content as a beta phase stabilizer on the microstructure and the mechanical properties of the $\mathrm{Ti}-\mathrm{Mo}-\mathrm{Nb}-(x) \mathrm{Mn}$ alloy;

- to determine the corrosion behaviour or biocompatibility of $\mathrm{Ti}-\mathrm{Mo}-\mathrm{Nb}-(x) \mathrm{Mn}$ alloys.

\section{Materials and methods for sample preparation and examination of composition, microstructure and properties of Ti-Mo-Nb based alloys}

In this study, quaternary $\mathrm{Ti}-9 \mathrm{Mo}-6 \mathrm{Nb}-(x) \mathrm{Mn}$ alloys with different amounts of added $\mathrm{Mn}$ in the range of $0-12 \mathrm{wt} \% \mathrm{Mn}$ were synthesized from pure titanium (99.9\%), pure niobium (99.5\%), pure molybdenum (99.5\%), and pure manganese $(99.5 \%)$. Sample preparation before the melting process in a vacuum arc furnace is to prepare raw materials $\mathrm{Ti}, \mathrm{Mo}, \mathrm{Nb}$ and $\mathrm{Mn}$ by cutting to the required size, then cleaned using volatile organic solvents, then weighing the raw materials in accordance with the calculation of the balance of materials and loading raw materials on crucible copper in the melting chamber. The $\mathrm{Ti}-\mathrm{Mo}-\mathrm{Nb}$-based titanium alloys were melted in an electric arc vacuum furnace containing nonconsumable electrodes (watercooled) under an argon atmosphere. The dimension of the as-cast sample is $\varnothing 24 \times 12 \mathrm{~mm}$. The melting process was carried out five times to improve the chemical homogeneity of the ingots. The samples were subsequently homogenized in a vacuum tube furnace at $1050{ }^{\circ} \mathrm{C}$ for $6 \mathrm{~h}$ under an argon atmosphere followed by cooling in the furnace, with the aim of enhancing the uniform distribution of the elements in the alloys.

The chemical compositions of the samples were analyzed using X-ray fluorescence (XRF), and the crystalline structures and phases of the alloys were characterized by X-ray diffraction (XRD) at ambient temperature using a Rigakusmartlab diffractometer, Japan. Metallographic observations and analysis of the alloy microstructures were carried out using an optical microscope (Meiji Techno, Japan)

Before carrying out any of the tests, the samples were cut and mounted using resin so that it is easy to handle during the sanding or polishing process. They were subsequently sanded using a piece of up to 2,000 grade $\mathrm{SiC}$ paper and mirrorpolished using pieces of 5,1 , and $0.3 \mu \mathrm{m}$ micropolish alumina, and etched using a solution of Kroll's reagent ( $2 \mathrm{~mL}$ of $\mathrm{HF}, 6 \mathrm{~mL}$ of $\mathrm{HNO}_{3}$, and $92 \mathrm{~mL}$ of $\mathrm{H}_{2} \mathrm{O}$ ). Vickers hardness measurements on the samples were carried out using a Vickers micro-hardness testing machine (Mitutoyo, Japan) with a $0.3 \mathrm{~N}$ load for $12 \mathrm{~s}$, and elastic modulus measurements were conducted using an ultrasonic method according to an ASTM-E494-95 standard [31, 32].

Samples with areas of $0.5 \mathrm{~cm}^{2}$ were used in the electrochemical tests; $\mathrm{Ag} / \mathrm{AgCl}$ was used as the reference electrodes, and platinum wire was used as the opposite electrode. The tests were carried out in lactated Ringer's solution at room temperature and neutral $\mathrm{pH}$.

\section{Experiment results of examination of composition, microstructure and properties of $\mathrm{Ti}-\mathrm{Mo}-\mathrm{Nb}$ based alloys}

The samples produced in the remelting process were ingots of around $20 \mathrm{~g}$ in weight, $24 \mathrm{~mm}$ in diameter, and $12 \mathrm{~mm}$ in thickness. The chemical compositions of the $\mathrm{Ti}-9 \mathrm{Mo}-6 \mathrm{Nb}-(x) \mathrm{Mn}$ alloy samples were investigated by carrying out XRF tests, the results of which are presented in Table 1.

Table 1

Chemical compositions of the $\mathrm{Ti}-9 \mathrm{Mo}-6 \mathrm{Nb}-(x) \mathrm{Mn}$ $(x=0,4,8$, and 12$)$ alloys

\begin{tabular}{|c|c|c|c|c|}
\hline Element & Mo & $\mathrm{Nb}$ & $\mathrm{Mn}$ & $\mathrm{Ti}$ \\
\hline Alloy & (wt \%) & (wt \%) & (wt \%) & (wt \%) \\
\hline $\begin{array}{c}\text { Ti-9Mo-6Nb } \\
(\mathrm{TMN}, 0 \% \mathrm{Mn})\end{array}$ & 9.097 & 5.657 & 0 & bal. \\
\hline $\begin{array}{c}\text { Ti-9Mo-6Nb-4Mn } \\
(\mathrm{TMN}, 4 \% \mathrm{Mn})\end{array}$ & 9.029 & 5.519 & 3.988 & bal. \\
\hline $\begin{array}{c}\text { Ti-9Mo-6Nb-8Mn } \\
(\mathrm{TMN}, 8 \% \mathrm{Mn})\end{array}$ & 9.212 & 5.606 & 7.178 & bal. \\
\hline $\begin{array}{c}\text { Ti-9Mo-6Nb-12Mn } \\
(\mathrm{TMN}, 12 \% \mathrm{Mn})\end{array}$ & 9.315 & 5.475 & 11.184 & bal. \\
\hline
\end{tabular}

Fig. 1 shows that from their XRD patterns, only two phases $(\alpha$ and $\beta$ ) can be observed in the Ti-9Mo-6Nb- $-(x) \mathrm{Mn}$ alloys.

Fig. 2 shows the microstructure observations on the Ti-9Mo-6Nb- $(x) \mathrm{Mn}$ alloys, it can be seen that exhibit a nearly equiaxed grain microstructure. It is observed that the higher the Mn content, the smaller the grain size.

Fig. 3 shows the microstructures of the $\mathrm{Ti}-9 \mathrm{Mo}-$ $6 \mathrm{Nb}-(x) \mathrm{Mn}$ alloys after homogenization at $1050{ }^{\circ} \mathrm{C}$ for $6 \mathrm{~h}$ and slow cooling in a furnace. 


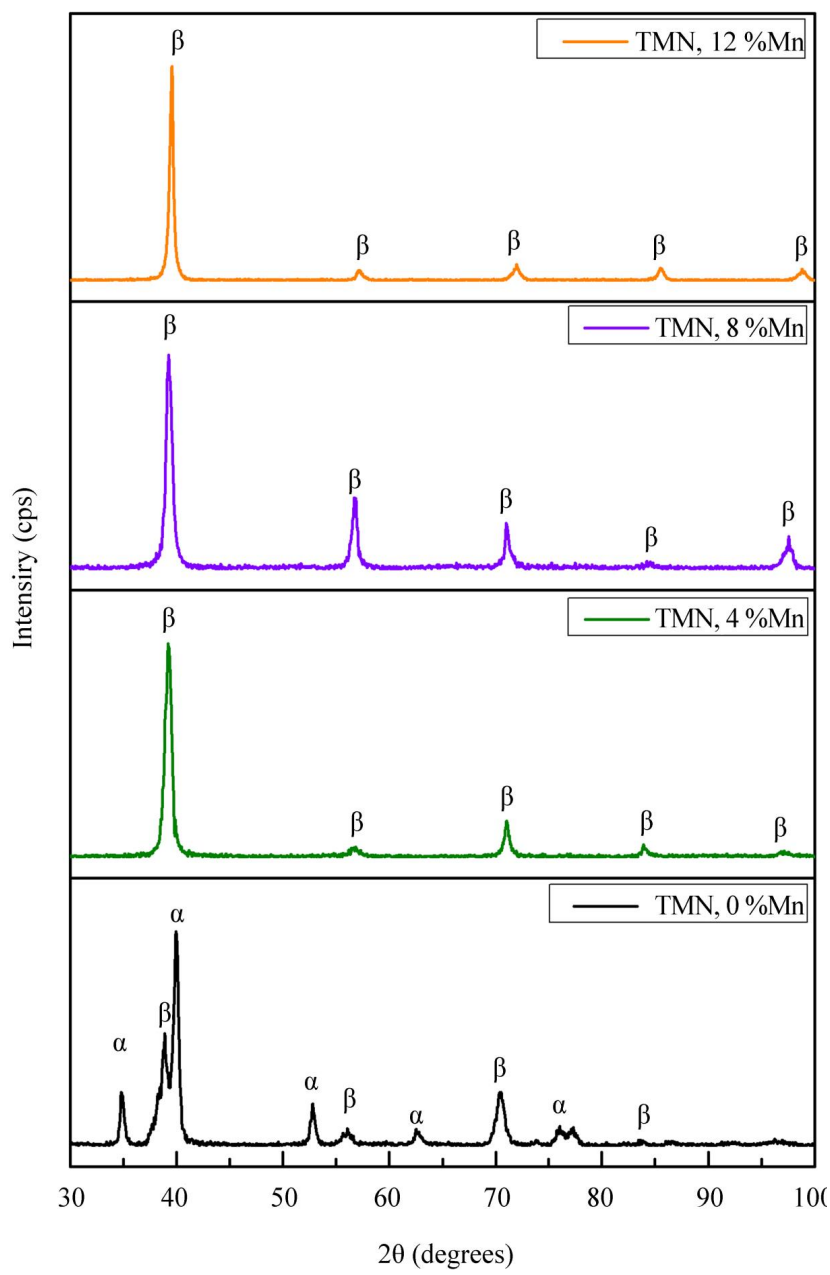

Fig. 1. Diffraction patterns of the Ti-9Mo $-6 \mathrm{Nb}-(x) \mathrm{Mn}$ $(x=0,4,8$, and 12$)$ alloys

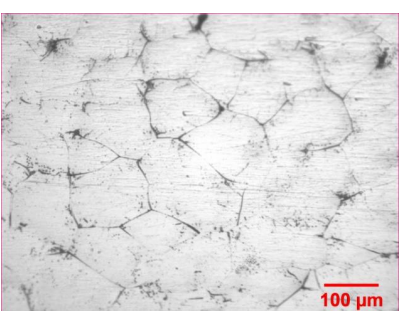

$a$

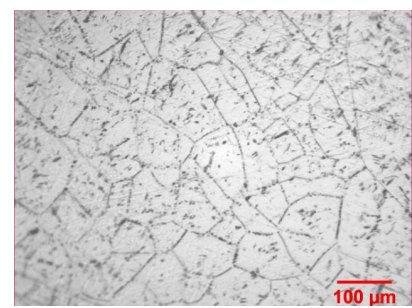

c

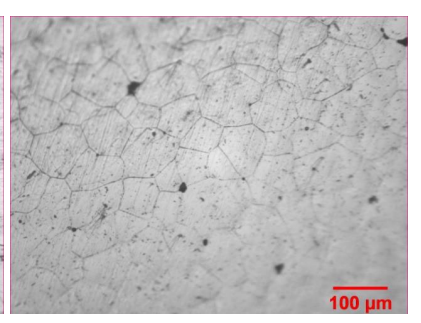

$b$

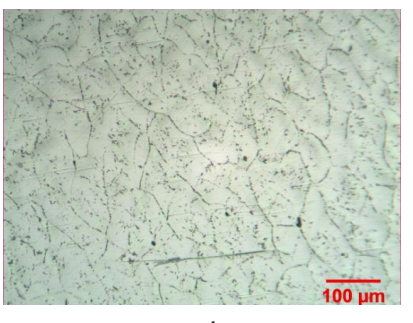

$d$
Fig. 2. As-cast sample microstructures of the Ti-9Mo-6Nb- $(x)$ Mn alloys: $a-x=0 \% \mathrm{Mn}$; $b-x=4 \% \mathrm{Mn} ; c-x=8 \% \mathrm{Mn} ; d-x=12 \% \mathrm{Mn}$

Tables 2, 3 show the average Vickers microhardness values of the as-cast $\mathrm{Ti}-9 \mathrm{Mo}-6 \mathrm{Nb}-(x) \mathrm{Mn}$ alloys before and after homogenization.

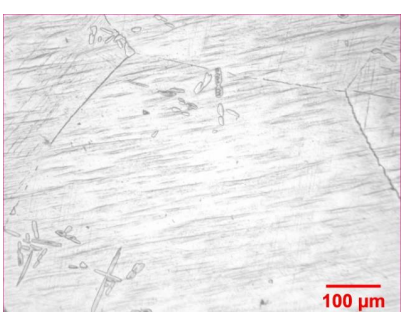

$a$

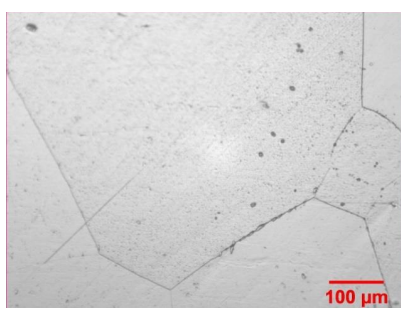

c

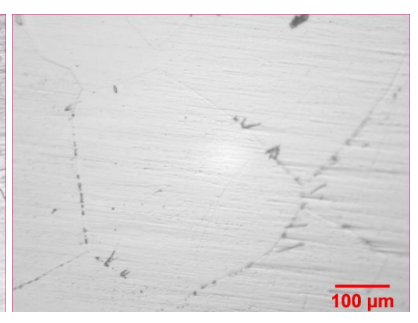

$b$

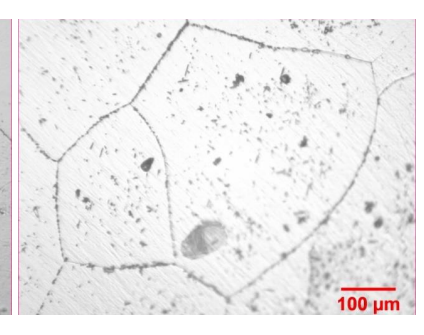

d
Fig. 3. Homogenized microstructures of the $\mathrm{Ti}-9 \mathrm{Mo}-6 \mathrm{Nb}-(x) \mathrm{Mn}$ alloys: $\mathrm{a}-x=0 \% \mathrm{Mn}$; $b-x=4 \% \mathrm{Mn} ; c-x=8 \% \mathrm{Mn} ; d-x=12 \% \mathrm{Mn})$

Table 2

Hardness value of the as-cast sample of the $\mathrm{Ti}-9 \mathrm{Mo}-6 \mathrm{Nb}-(x) \mathrm{Mn}(x=0,4,8$, and 12$)$ alloys

\begin{tabular}{|c|c|c|c|c|}
\hline Sample & \multicolumn{4}{|c|}{ HV } \\
\hline Alloy & 1 & 2 & 3 & Average \\
\hline $\begin{array}{c}\text { Ti-9Mo-6Nb } \\
(\mathrm{TMN}, 0 \% \mathrm{Mn})\end{array}$ & 439.0 & 420.0 & 444.0 & 434.3 \\
\hline $\begin{array}{c}\text { Ti-9Mo-6Nb-4Mn } \\
(\mathrm{TMN}, 4 \% \mathrm{Mn})\end{array}$ & 375.0 & 376.5 & 386.4 & 379.3 \\
\hline $\begin{array}{c}\text { Ti-9Mo-6Nb-8Mn } \\
(\mathrm{TMN}, 8 \% \mathrm{Mn})\end{array}$ & 375.0 & 358.0 & 340.7 & 357.9 \\
\hline $\begin{array}{c}\text { Ti-9Mo-6Nb-12Mn } \\
(\mathrm{TMN}, 12 \% \mathrm{Mn})\end{array}$ & 335.9 & 339.5 & 341.8 & 339.1 \\
\hline
\end{tabular}

Table 3

Hardness value of the as-cast sample of the $\mathrm{Ti}-9 \mathrm{Mo}-6 \mathrm{Nb}-(x) \mathrm{Mn}(x=0,4,8$, and 12$)$ alloys after homogenization

\begin{tabular}{|c|c|c|c|c|}
\hline Sample & \multicolumn{4}{|c|}{ HV } \\
\hline Alloy & 1 & 2 & 3 & Average \\
\hline $\begin{array}{c}\text { Ti-9Mo-6Nb } \\
(\mathrm{TMN}, 0 \% \mathrm{Mn})\end{array}$ & 478.0 & 496.2 & 465.9 & 480.0 \\
\hline $\begin{array}{c}\text { Ti-9Mo-6Nb-4Mn } \\
(\mathrm{TMN}, 4 \% \mathrm{Mn})\end{array}$ & 441.4 & 459.3 & 464.4 & 455.0 \\
\hline $\begin{array}{c}\text { Ti-9Mo-6Nb-8Mn } \\
(\mathrm{TMN}, 8 \% \mathrm{Mn})\end{array}$ & 426.4 & 410.7 & 426.4 & 421.2 \\
\hline $\begin{array}{c}\text { Ti-9Mo-6Nb-12Mn } \\
(\mathrm{TMN}, 12 \% \mathrm{Mn})\end{array}$ & 404.7 & 359.0 & 411.5 & 391.7 \\
\hline
\end{tabular}

Table 4 shows the elastic modulus values of the as-cast $\mathrm{Ti}-9 \mathrm{Mo}-6 \mathrm{Nb}-(x) \mathrm{Mn}$ alloys before and after homogenization.

In vitro biocompatibility tests were then conducted by carrying out corrosion tests to evaluate the behavior or the rate of corrosion of the samples in Ringer's solution [4] at $25^{\circ} \mathrm{C}$. These were in the form of linear potentiodynamic polarization tests, the results of which are presented as an active-passive graph and corrosion rates, Table 5 . 
Table 4

Elastic modulus values of the as-cast Ti-9Mo-6 Nb- $-(x) \mathrm{Mn}$ alloys before and after homogenization

\begin{tabular}{|c|c|c|}
\hline Sample & \multicolumn{2}{|c|}{ Elastic Modulus (GPa) } \\
\hline Alloy & As-cast sample & Homogenized sample \\
\hline $\begin{array}{c}\text { Ti-9Mo-6Nb } \\
\text { (TMN, 0 \%Mn) }\end{array}$ & 98 & 99 \\
\hline $\begin{array}{c}\text { Ti-9Mo-6Nb-4Mn } \\
\text { (TMN, 4\%Mn) }\end{array}$ & 94 & 96 \\
\hline $\begin{array}{c}\text { Ti-9Mo-6Nb-8Mn } \\
\text { (TMN, 8\%Mn) }\end{array}$ & 93 & 98 \\
\hline $\begin{array}{c}\text { Ti-9Mo-6Nb-12Mn } \\
\text { (TMN, 12\%Mn) }\end{array}$ & 98 & 101 \\
\hline
\end{tabular}

Table 5

Corrosion properties of the $\mathrm{Ti}-9 \mathrm{Mo}-6 \mathrm{Nb}-(x) \mathrm{Mn}$ alloys in Ringer's solution

\begin{tabular}{|c|c|c|c|}
\hline Alloy & $\begin{array}{c}\text { Corrosion } \\
\text { Potential } \\
\mathrm{E}_{\text {corr }}\left(\mathrm{V}_{\mathrm{Ag} / \mathrm{ACl}}\right)\end{array}$ & $\begin{array}{c}\text { Corrosion } \\
\text { Current } \\
\text { Density } \\
\left(\mathrm{I} / \mathrm{Im}^{2}\right)\end{array}$ & $\begin{array}{c}\text { Corrosion } \\
\text { Rate } \\
(\mathrm{mmpy})\end{array}$ \\
\hline $\mathrm{Ti}-9 \mathrm{Mo}-6 \mathrm{Nb}$ & -0.472 & 2.640 & 0.04012 \\
\hline $\mathrm{Ti}-9 \mathrm{Mo}-6 \mathrm{Nb}-4 \mathrm{Mn}$ & -0.408 & 0.194 & 0.00290 \\
\hline $\mathrm{Ti}-9 \mathrm{Mo}-6 \mathrm{Nb}-8 \mathrm{Mn}$ & -0.189 & 0.224 & 0.00327 \\
\hline $\mathrm{Ti}-9 \mathrm{Mo}-6 \mathrm{Nb}-12 \mathrm{Mn}$ & -0.383 & 0.248 & 0.00366 \\
\hline $\mathrm{Ti}-6 \mathrm{Al}-4 \mathrm{~V}$ & -0.343 & 0.235 & 0.00401 \\
\hline
\end{tabular}

\section{Discussion of microstructure, mechanical properties and corrosion behavior of new $\beta$-type Ti-Mo-Nb based alloys}

Fig. 1 shows that from their XRD patterns, only two phases $(\alpha$ and $\beta$ ) can be observed in the Ti-9Mo-6 $-6 b-(x) \mathrm{Mn}$ alloys. The $\alpha$-phase peak indicates that the alloy has an HCP crystal structure with a (101) crystal orientation. The titanium $\alpha$-phase peak was observed to decrease and eventually disappear when $\mathrm{Mn}$ was added as a $\beta$-stabilizer, resulting in the material becoming a full $\beta$-phase with a body-centered cubic crystal structure, the crystal orientations of which are $\beta(110), \beta(200), \beta(211)$, and $\beta(220)[27,28]$.

From Fig. 1, it can be seen that the $\beta$-phase of the $\mathrm{Ti}-9 \mathrm{Mo}-6 \mathrm{Nb}-(x) \mathrm{Mn}$ alloy gives rise to diffraction pattern peaks with $2 \theta$-angle positions of $39.5^{\circ}, 56.9^{\circ}, 70.5^{\circ}$, and $85^{\circ}[33,34]$. The detected $\alpha$-phase in the alloy containing $0 \% \mathrm{Mn}$ content exhibits peaks at $35.6^{\circ}, 40.5^{\circ}, 53^{\circ}$, and $77^{\circ}$. The XRD results are in line with the results of the microstructure observations shown in Fig. 2,3. The presence of the $\alpha$-phase in the alloy here was very small, possibly only at the grain boundaries or when precipitating. The $\alpha$-phase was seen at the grain boundaries of the $\beta$-phase in the sample, a result that is in good agreement with that reported [35].

From the microstructure observations on the $\mathrm{Ti}-9 \mathrm{Mo}-$ $6 \mathrm{Nb}-(x) \mathrm{Mn}$ alloys shown in Fig. 2, it can be seen that all the materials exhibit a nearly equiaxed grain microstructure, which has a $\beta$-structure with $50-100-\mu \mathrm{m}$-long grains. It is observed that the higher the Mn content, the smaller the grain size. Mn added to the alloy positively stabilized the $\beta$-phase, so that the microstructure of the alloy only contains the $\beta$-phase, a result that is in good agreement with the XRD measurements. The calculation results show that the Mo equivalent of the $\mathrm{Ti}-9 \mathrm{Mo}-6 \mathrm{Nb}-(x) \mathrm{Mn}$ alloys have $\mathrm{Mo}$ equivalent values greater than $10 \%$, so these alloys fall into the $\beta$-metastable category [34, 35].

After homogenization, the microstructures showed a similarity in their grain sizes, with an average size of equiaxed $\beta$-grains of $200 \mu \mathrm{m}$. The $\alpha$-phase detected in the XRD pattern of the $\mathrm{Ti}-9 \mathrm{Mo}-6 \mathrm{Nb}$ sample before the addition of $\mathrm{Mn}$ is shown in the $\alpha$-lamellar form in Fig. 3, $a$ and shown in the equiaxed $\beta$ from Fig. $3, b-d$.

Fig. 4 shows the average Vickers microhardness values of the as-cast $\mathrm{Ti}-9 \mathrm{Mo}-6 \mathrm{Nb}-(x) \mathrm{Mn}$ alloys before and after homogenization, where after homogenization, the Vickers hardness value increased by up to $20 \%$. Because the $\alpha$-phase is fragile and hard, its presence in the $\mathrm{Ti}-9 \mathrm{Mo}-6 \mathrm{Mn}$ alloy resulted in a relatively high hardness value. The hardness value decreased on the addition of $\mathrm{Mn}$ because of an increase in the $\beta$-phase.

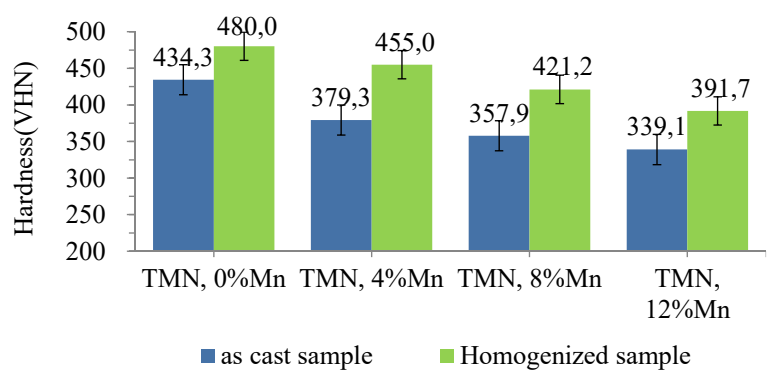

Fig. 4. Vickers hardness values of the Ti-9Mo-6 $\mathrm{Nb}-(x) \mathrm{Mn}$ $(x=0,4,8$, and 12) alloys

It has been reported that $\alpha$-phase materials have higher elastic modulus values than $\beta$-phase materials, with the elastic modulus of the titanium alloy phases increasing in the order of $\beta<\alpha^{\prime \prime}<\alpha^{\prime}<\omega[32,36,37]$. Hon et al. reported that different phases have different elastic modulus; for example, $\mathrm{E} \alpha=1.5 \mathrm{E} \beta$ and $\mathrm{E} \omega=2.0 \mathrm{E} \beta$ [32].

Fig. 5 shows the elastic modulus values of the as-cast $\mathrm{Ti}-9 \mathrm{Mo}-6 \mathrm{Nb}-(x) \mathrm{Mn}$ alloys before and after homogenization, where the addition of $\mathrm{Mn}$ results in a decrease in the elastic modulus of the alloys before homogenization. The alloy containing $4 \% \mathrm{Mn}$ showed the lowest elastic modulus after homogenization, with a value of $96 \mathrm{GPa}$. The homogenization of the $\mathrm{Ti}-9 \mathrm{Mo}-6 \mathrm{Nb}$ alloy with added $\mathrm{Mn}$ caused the elastic modulus of the material to increase to $101 \mathrm{GPa}$. However, $\beta$-type titanium alloys were observed to have lower elastic modulus than Ti-6Al-4V(115 GPa) and $\beta$-type $\mathrm{Ti}-12 \mathrm{Mo}-3 \mathrm{Nb}(105 \mathrm{GPa})$ alloys, as indicated by the dashed line in Fig. 5 [34].

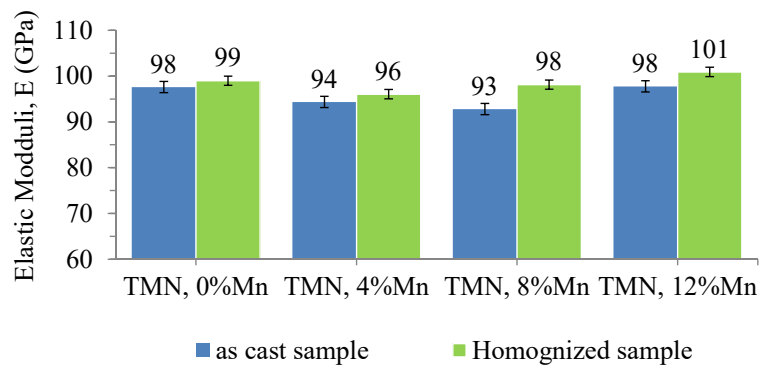

Fig. 5. Elastic modulus values of the $\mathrm{Ti}-9 \mathrm{Mo}-6 \mathrm{Nb}-(x) \mathrm{Mn}(x=0,4,8$, and 12$)$ alloys

Fig. 6 shows the polarization curves of the Ti-9Mo$6 \mathrm{Nb}-(x) \mathrm{Mn}$ alloys in Ringer's solution, which is used to 
simulate human bodily fluids. As a comparison, corrosion tests were also carried out in the same solution using commercial Ti-6Al-4V. Fig. 6 shows a Tafel diagram indicating that the $\mathrm{Ti}-9 \mathrm{Mo}-6 \mathrm{Nb}, \mathrm{Ti}-9 \mathrm{Mo}-6 \mathrm{Nb}-4 \mathrm{Mn}$, $\mathrm{Ti}-9 \mathrm{Mo}-6 \mathrm{Nb}-8 \mathrm{Mn}$, and $\mathrm{Ti}-9 \mathrm{Mo}-6 \mathrm{Nb}-12 \mathrm{Mn}$ alloys show better corrosion resistance than the commercial $\mathrm{Ti}-6 \mathrm{Al}-4 \mathrm{~V}$ alloy.

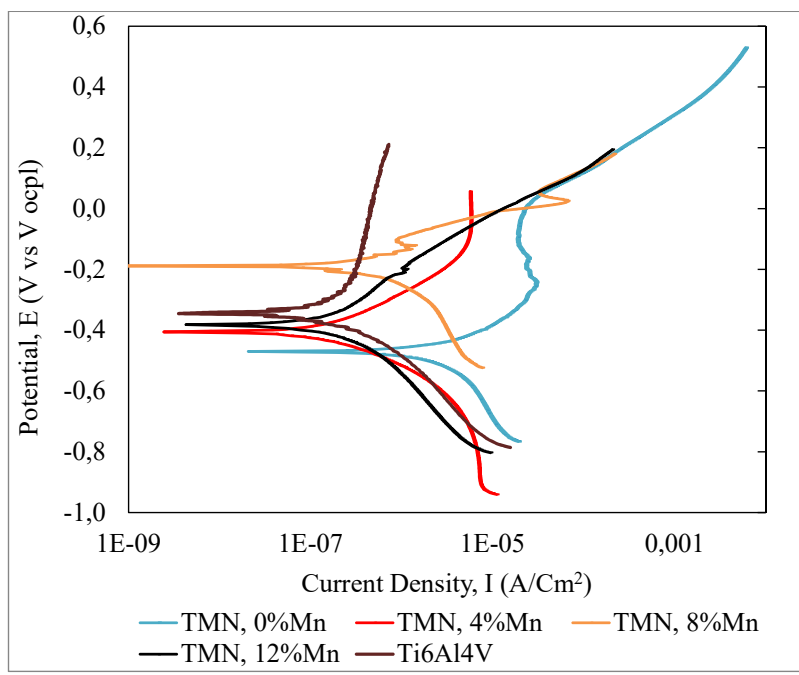

Fig. 6. Polarization curves of the Ti-9Mo-6Nb- $(x) \mathrm{Mn}$ $(x=0,4,8$, and 12$)$ alloys in Ringer's solution

Table 5 shows potentiodynamic corrosion test data, indicating the following:

1. The $\mathrm{Ti}-9 \mathrm{Mo}-6 \mathrm{Nb}, \mathrm{Ti}-9 \mathrm{Mo}-6 \mathrm{Nb}-4 \mathrm{Mn}, \mathrm{Ti}-9 \mathrm{Mo}-$ $6 \mathrm{Nb}-8 \mathrm{Mn}$, and $\mathrm{Ti}-9 \mathrm{Mo}-6 \mathrm{Nb}-12 \mathrm{Mn}$ alloys show better corrosion resistance than a commercial $\mathrm{Ti}-6 \mathrm{Al}-4 \mathrm{~V}$ alloy when tested in Ringer's solution.

2. When Mn was added to the $\mathrm{Ti}-9 \mathrm{Mo}-6 \mathrm{Nb}$ alloys, it tended to reduce the corrosion rates of the materials, but when the $\mathrm{Mn}$ content was increased, the corrosion rate increased. The corrosion rate of the $\beta$-type Ti-9Mo- $6 \mathrm{Nb}-4 \mathrm{Mn}$ alloy with $4 \% \mathrm{Mn}$ was the lowest among the alloys, at $0.00290 \mathrm{~mm}$ per year (mmpy), much lower than that of $\mathrm{Ti}-6 \mathrm{Al}-4 \mathrm{~V}$ at $0.00401 \mathrm{mmpy}$.

A further increase in the addition of Mn to the alloys resulted in an increase in the corrosion resistance, because $\mathrm{Mn}$ increases the cathodic reaction that changes the titanium oxide layers, making them more stable and dense, which in turn prevents fast corrosion [38]. Consequently, the cytotoxicity of titanium as a biomaterial must be further investigated and will be the subject of our future work.
The advantages of this research are:

- improved mechanical properties and corrosion resistance of Titanium alloys, especially modulus of elasticity with better results than Ti4Al6V alloys;

- development of biocompatible materials using toxic-free and low-cost alloys.

The disadvantage of this study is the still relatively high elastic modulus compared to that of human bones, so that further heat treatment is necessary.

The results of this study can be used to improve the quality of implant material. The development of titanium alloys is used in the medical field for permanent implant materials, especially for orthopedic applications. This titanium alloy in biomedical applications is used as a fixation plate, screw, wire, pins, total knee replacement and hip joint components. This research is a continuation of previous studies that are to improve the mechanical properties of TiAlMo and TiAlNb alloys.

\section{Conclusions}

1. The addition of Mn elements in Ti-9Mo-6Nb alloys affected the microstructure with a beta phase formation characterized by equiaxed grain structure. With the increasing $\mathrm{Mn}$ content, the finer grains could reach 50 microns in size. After adding different $\mathrm{Mn}$ contents, it was found that the alloy with $4 \% \mathrm{Mn}$ had the greatest hardness and the lowest elastic modulus of $96 \mathrm{GP}$.

2. The addition of Mn elements on Ti-9Mo-6 Nb alloys reduced the corrosion rate leading to the increase in corrosion resistance. Alloys with $4 \% \mathrm{Mn}$ content have the best corrosion resistance with a relatively low corrosion rate of 0.00290 mmpy compared to commercial Ti-6Al-4V alloys.

Therefore, taking into account all the mechanical properties and corrosion behaviors, the new $\beta$-type Ti-9Mo-6Nb alloys are proposed to be potential candidates to replace $\mathrm{Ti}-6 \mathrm{Al}-4 \mathrm{~V}$ alloys.

\section{Acknowledgements}

We would like to thank the Ministry of Research and Higher Education of the Republic of Indonesia for their financial support through the Doctoral Disseration (PDD) research grand with contract number of 1/E1/KP.PTNBH/2019 and 234/PKS/R/UI/2019 dae March 12, 2019 and 1834/UN2. R3.1/HKP.05.00/2019. The author would like to thank the Reseearch Center for Metallurgy and Materials Indonesia Institute of Siences for the support of laboratory facilities.

\section{References}

1. Niinomi, M. (2008). Metallic biomaterials. Journal of Artificial Organs, 11 (3), 105-110. doi: https://doi.org/10.1007/s10047008-0422-7

2. Mareci, D., Bolat, G., Chelariu, R., Sutiman, D., Munteanu, C. (2013). The estimation of corrosion behaviour of ZrTi binary alloys for dental applications using electrochemical techniques. Materials Chemistry and Physics, 141 (1), 362-369. doi: https://doi.org/ 10.1016/j.matchemphys.2013.05.024

3. Niinomi, M. (2008). Mechanical biocompatibilities of titanium alloys for biomedical applications. Journal of the Mechanical Behavior of Biomedical Materials, 1 (1), 30-42. doi: https://doi.org/10.1016/j.jmbbm.2007.07.001

4. O'Brien, B., Stinson, J., Carroll, W. (2008). Initial exploration of Ti-Ta, Ti-Ta-Ir and Ti-Ir alloys: Candidate materials for coronary stents. Acta Biomaterialia, 4 (5), 1553-1559. doi: https://doi.org/10.1016/j.actbio.2008.03.002 
5. K Cho, K., Niinomi, M., Nakai, M., Hieda, J., \& Kawasaki, Y. (2013). Development of High Modulus Ti-Fe-Cu Alloys for Biomedical Applications. MATERIALS TRANSACTIONS, 54 (4), 574-581. doi: https://doi.org/10.2320/matertrans.m2012361

6. Geetha, M., Singh, A. K., Asokamani, R., Gogia, A. K. (2009). Ti based biomaterials, the ultimate choice for orthopaedic implants A review. Progress in Materials Science, 54 (3), 397-425. doi: https://doi.org/10.1016/j.pmatsci.2008.06.004

7. Li, Y., Yang, C., Zhao, H., Qu, S., Li, X., Li, Y. (2014). New Developments of Ti-Based Alloys for Biomedical Applications. Materials, 7 (3), 1709-1800. doi: https://doi.org/10.3390/ma7031709

8. Niinomi, M., Nakai, M., Hieda, J. (2012). Development of new metallic alloys for biomedical applications. Acta Biomaterialia, 8 (11), 3888-3903. doi: https://doi.org/10.1016/j.actbio.2012.06.037

9. Talib, M. M., Khan, Z., Siddiquee, A. N. (2014). Beta Titanium Alloys: The Lowest Elastic Modulus for Biomedical Applications: A Review. World Academy of Science, Engineering and Technology International Journal of Materials and Metallurgical Engineering, 8 (8), 822-827.

10. Gil Mur, F. X., Rodríguez, D., Planell, J. A. (1996). Influence of tempering temperature and time on the $\alpha^{\prime}-$ Ti-6Al-4V martensite. Journal of Alloys and Compounds, 234 (2), 287-289. doi: https://doi.org/10.1016/0925-8388(95)02057-8

11. Wanying, L., Yuanhua, L., Yuhai, C., Taihe, S., Singh, A. (2017). Effect of Different Heat Treatments on Microstructure and Mechanical Properties of Ti6Al4V Titanium Alloy. Rare Metal Materials and Engineering, 46 (3), 634-639. doi: https://doi.org/ 10.1016/s1875-5372(17)30109-1

12. Venkatesh, B. D., Chen, D. L., Bhole, S. D. (2009). Effect of heat treatment on mechanical properties of Ti-6Al-4V ELI alloy. Materials Science and Engineering: A, 506 (1-2), 117-124. doi: https://doi.org/10.1016/j.msea.2008.11.018

13. Perl, D. P. (1985). Relationship of Aluminum to Alzheimer's Disease. Environmental Health Perspectives, 63, $149-153$.

14. Domingo, J. L. (2002). Vanadium and Tungsten Derivatives as Antidiabetic Agents. Biological Trace Element Research, 88 (2), 097-112. doi: https://doi.org/10.1385/bter:88:2:097

15. Marsumi, Y., Pramono, A. W. (2014). Influence of Niobium or Molybdenum in Titanium Alloy for Permanent Implant Application. Advanced Materials Research, 900, 53-63. doi: https://doi.org/10.4028/www.scientific.net/amr.900.53

16. Senopati, G., Sutowo, C., P. A., I. N. G., Utomo, E. P., Amal, M. I. (2016). Microstructure and mechanical properties of as-cast Ti-Mo-xCr alloy for biomedical application. AIP Conference Proceedings, 1711, 050005. doi: https://doi.org/10.1063/1.4941631

17. Senopati, G., Sutowo, C., Amal, M. I. (2017). Mechanical properties, microstructure, and biocompatibility of Ti-6Al-6Nb. Journal of Physics: Conference Series, 817, 012012. doi: https://doi.org/10.1088/1742-6596/817/1/012012

18. Williams, D. F. (1986). Definitions in biomaterials: proceedings of a consensus conference of the European Society for Biomaterials. Vol. 4. Elsevier.

19. Hosseini, S. (2012). Fatigue of Ti-6Al-4V. Biomedical Engineering - Technical Applications in Medicine. doi: https://doi.org/ $10.5772 / 45753$

20. Properties and Selection: Nonferrous Alloys and Special-Purpose Materials (1990). Vol. 2. ASM International. doi: https:// doi.org/10.31399/asm.hb.v02.9781627081627

21. Sutowo, C., Rokhmanto, F., Senopati, G. (2017). Thermomechanical treatment process of $\alpha / \beta$ Ti-6Al-6Mo alloy as new alternative materials for biomedical application. Widyariset, 3 (1), 47-54. doi: https://doi.org/10.14203/widyariset.3.1.2017.47-54

22. Zhao, X., Niinomi, M., Nakai, M., Hieda, J. (2012). Beta type Ti-Mo alloys with changeable Young's modulus for spinal fixation applications. Acta Biomaterialia, 8 (5), 1990-1997. doi: https://doi.org/10.1016/j.actbio.2012.02.004

23. Zhang, W., Liu, Y., Wu, H., Song, M., Zhang, T., Lan, X., Yao, T. (2015). Elastic modulus of phases in Ti-Mo alloys. Materials Characterization, 106, 302-307. doi: https://doi.org/10.1016/j.matchar.2015.06.008

24. Abd-elrhman Yasser, Gepreel, M. A.-H., Abdel-Moniem, A., Kobayashi, S. (2016). Compatibility assessment of new V-free lowcost Ti-4.7Mo-4.5Fe alloy for some biomedical applications. Materials \& Design, 97, 445-453. doi: https://doi.org/10.1016/ j.matdes.2016.02.110

25. Xu, L. J., Chen, Y. Y., Liu, Z. G., Kong, F. T. (2008). The microstructure and properties of Ti-Mo-Nb alloys for biomedical application. Journal of Alloys and Compounds, 453 (1-2), 320-324. doi: https://doi.org/10.1016/j.jallcom.2006.11.144

26. Chelariu, R., Bolat, G., Izquierdo, J., Mareci, D., Gordin, D. M., Gloriant, T., Souto, R. M. (2014). Metastable beta Ti-Nb-Mo alloys with improved corrosion resistance in saline solution. Electrochimica Acta, 137, 280-289. doi: https://doi.org/10.1016/ j.electacta.2014.06.021

27. Neacsu, P., Gordin, D.-M., Mitran, V., Gloriant, T., Costache, M., Cimpean, A. (2015). In vitro performance assessment of new beta Ti-Mo-Nb alloy compositions. Materials Science and Engineering: C, 47, 105-113. doi: https://doi.org/10.1016/ j.msec.2014.11.023

28. Sutowo, C., Senopati, G., Supriadi, S., Pramono, A. W., Suharno, B. (2019). The Influence of Sn addition on the microstructure and mechanical properties of the new $\beta$-type Ti-Mo-Nb based alloys for implant material. IOP Conference Series: Materials Science and Engineering, 541, 012036. doi: https://doi.org/10.1088/1757-899x/541/1/012036 
29. Santos, P. F., Niinomi, M., Cho, K., Nakai, M., Liu, H., Ohtsu, N. et. al. (2015). Microstructures, mechanical properties and cytotoxicity of low cost beta Ti-Mn alloys for biomedical applications. Acta Biomaterialia, 26, 366-376. doi: https://doi.org/ 10.1016/j.actbio.2015.08.015

30. ASTM E494-95. Standard Practice for Measuring Ultrasonic Velocity in Materials. ASTM International. doi: https://doi.org/ 10.1520/e0494-95

31. Majumdar, P., Singh, S. B., Chakraborty, M. (2008). Elastic modulus of biomedical titanium alloys by nano-indentation and ultrasonic techniques - A comparative study. Materials Science and Engineering: A, 489 (1-2), 419-425. doi: https://doi.org/ 10.1016/j.msea.2007.12.029

32. Chen, Z., Liu, Y., Jiang, H., Liu, M., Wang, C. H., Cao, G. H. (2017). Microstructures and mechanical properties of Mn modified, Ti-Nb-based alloys. Journal of Alloys and Compounds, 723, 1091-1097. doi: https://doi.org/10.1016/j.jallcom.2017.06.311

33. Gabriel, S. B., Panaino, J. V. P., Santos, I. D., Araujo, L. S., Mei, P. R., de Almeida, L. H., Nunes, C. A. (2012). Characterization of a new beta titanium alloy, Ti-12Mo-3Nb, for biomedical applications. Journal of Alloys and Compounds, 536, S208-S210. doi: https://doi.org/10.1016/j.jallcom.2011.11.035

34. Zhang, D. C., Tan, C. G., Tang, D. M., Zhang, Y., Lin, J. G., Wen, C. E. (2014). Effect of thermomechanical treatment on the superelasticity of Ti-7.5Nb-4Mo-2Sn biomedical alloy. Materials Science and Engineering: C, 44, 76-86. doi: https://doi.org/ $10.1016 /$ j.msec.2014.08.001

35. Zhang, L., Wang, K., Xu, L., Xiao, S., Chen, Y. (2015). Effect of Nb addition on microstructure, mechanical properties and castability of $\beta$-type Ti-Mo alloys. Transactions of Nonferrous Metals Society of China, 25 (7), 2214-2220. doi: https://doi.org/ 10.1016/s1003-6326(15)63834-1

36. Banerjee, R., Nag, S., Fraser, H. L. (2005). A novel combinatorial approach to the development of beta titanium alloys for orthopaedic implants. Materials Science and Engineering: C, 25 (3), 282-289. doi: https://doi.org/10.1016/j.msec.2004.12.010

37. Hon, Y.-H., Wang, J.-Y., Pan, Y.-N. (2003). Composition/Phase Structure and Properties of Titanium-Niobium Alloys. MATERIALS TRANSACTIONS, 44 (11), 2384-2390. doi: https://doi.org/10.2320/matertrans.44.2384

38. Kim, J.-W., Hwang, M.-J., Han, M.-K., Kim, Y.-G., Song, H.-J., Park, Y.-J. (2016). Effect of manganese on the microstructure, mechanical properties and corrosion behavior of titanium alloys. Materials Chemistry and Physics, 180, 341-348. doi: https:// doi.org/10.1016/j.matchemphys.2016.06.016 